\title{
INTERNATIONAL STANDARDS FOR PROPERTIES AND PERFORMANCE OF ADVANCED CERAMICS - 30 YEARS OF EXCELLENCE
}

\author{
Michael G. Jenkins, Bothell Engineering \& Science Technologies, Bothell, WA, USA, \\ Jonathan A. Salem, NASA Glenn Research Center, Cleveland, OH, USA, \\ jenkinsmg@bothellest.com \\ jonathan.a.salem@nasa.gov
}

John Helfinstine, Corning Inc Retiree \& Consultant, Big Flats, NY, USA,

George D. Quinn, Government Retiree \& Consultant, NIST, Gaithersburg, MD, USA,

veakin@earthlink.net

Stephen T. Gonczy, Gateway Materials Technology, Inc., Mt. Prospect, IL, USA,

george.quinn@nist.gov

gatewaymt@aol.com

ABSTRACT

Mechanical and physical properties/performance of brittle bodies (e.g., advanced ceramics and glasses) can be difficult to measure correctly unless the proper techniques are used. For three decades, ASTM Committee $\mathrm{C} 28$ on Advanced Ceramics, has developed numerous full-consensus standards (e.g., test methods, practices, guides, terminology) to measure various properties and performance of a monolithic and composite ceramics and coatings that, in some cases, may be applicable to glasses. These standards give the "what, how, how not, why, why not, etc." for many mechanical, physical, thermal, properties and performance of advanced ceramics. Use of these standards provides accurate, reliable, repeatable and complete data. Involvement in ASTM Committee C28 has included users, producers, researchers, designers, academicians, etc. who write, continually update, and validate through round robin test programmes, more than 45 standards in the 30 years since the Committee's inception in 1986. Included in this poster is a pictogram of the ASTM Committee C28 standards and how to obtain them either as i) individual copies with full details or ii) a complete collection in one volume. A listing of other ASTM committees of interest is included. In addition, some examples of the tangible benefits of standards for advanced ceramics are employed to demonstrate their practical application.

KEYWORDS - ceramics, composites, coatings, standards, characterizations, properties, measurements.

\section{INTRODUCTION AND BACKGROUND}

It is noteworthy that the $30^{\text {th }}$ anniversary year of ASTM Committee C28 "Advanced Ceramics," coincides with 40th International Conference and Expo on Advanced Ceramics and Composites. This is not mere happenstance but instead reflects the driving forces and visionaries of the early to mid 1980's who recognized that the time had come for ceramics to become commonly recognized, used, and fabricated among the four commonly accepted classes of engineering materials: Metals; Ceramics/Glasses; Polymers; Composites.

Advanced ceramics is the accepted term in the United States for what are also known as engineering ceramics, structural ceramics, fine ceramics, and technical ceramics. By definition [1] an advanced ceramics is: a highly engineered, high performance, predominately non-metallic, inorganic, ceramic material having specific functional attributes. Historically, technological evolution has been the driver to push material performance requirements far beyond those normally satisfied by common engineering materials. As engineering demands for advanced technology applications increased, materials (including ceramics along with modern composites) were the enabling technology and as it turned out, standards and design codes, were the enabling supporting technologies. 
Until about 1980, most uses for ceramics in engineering applications were for situations involving wear-resistance or low stress or electrical insulation or some combination of these. Although many advanced technology applications of ceramics may seem common today, in the mid 1980's they were potential not actual applications: microprocessor substrates, gas turbine vanes and blades, ball bearings, hip joints, ballistic armor, window panes, cutting blades, sensors, electrolytes, to name a few. Indeed, the market prognosticators were keen on high temperature applications such as future heat engines, both reciprocating and turbines

In light of the growing and projected applications of advanced ceramics, in 1985, the Engineering Ceramics Division of the American Ceramic Society evolved out of the long-standing Ceramic-Metal Systems Division. For similar reasons, in 1986 Committee C28 Advanced Ceramics of American Society for Testing and Materials (now ASTM International) was formed as a new stand-alone committee separate from a subcommittee within Committee C08 Refractories.

The scope of Committee C28 includes the promotion of knowledge, stimulation of research and development of standards (classifications, specifications, nomenclature, test methods, guides, and practices) relating to processing, properties, characterization, and performance of advanced ceramic materials. Committee C28 works in concert with other technical committees (e.g., D30 "Composite Materials," E07 "Non Destructive Testing," E08 "Fatigue and Fracture," E28 "Mechanical Testing," F04 "Medical and Surgical Materials and Devices", and G02 "Wear and Erosion") and other national and international organizations having mutual or related interests.

Committee C28 develops and maintains standards for monolithic and composite advanced ceramics. Standards of Committee C28 cover methods for testing bulk and constituent (powders, fibres, etc.) properties, thermal and physical properties, strengths and strength distributions, and performance under varying environmental, thermal, and mechanical conditions. The breadth of applications of the methods ranges from quality control through design data generation. The Committee's primary objective is the development of technically rigorous standards which are accessible to the general industrial laboratory and consequently are widely accepted and used in the design, production, and utilization of advanced ceramics.

It is useful to know that ASTM International is the primary standards writing organization (SWO) for testing materials in the United States and is a private nonprofit corporation for the development of voluntary, full-consensus standards on the characteristics and performance of materials, products, systems, and services and for the promotion of related knowledge. These efforts are accomplished through the work of various ASTM committees consisting of volunteer experts, who, following previously established regulations generate a product (i.e., a standard) that is widely recognized, high quality, well accepted and generally used. ASTM standards are classified as test methods, practices, nomenclature and guides.

In this paper, details are provided for various periods the 30 years of existence of Committee C28: Early Years - Direction and Growth (1986-93); Transition Years - International Harmonization (19932006); Present Years - Applications and Validation (2006-Today). Finally, some examples of the tangible benefits of standards for advanced ceramics are employed to demonstrate their practical applications. 


\section{ASTM Committee C28 Advanced Ceramics}

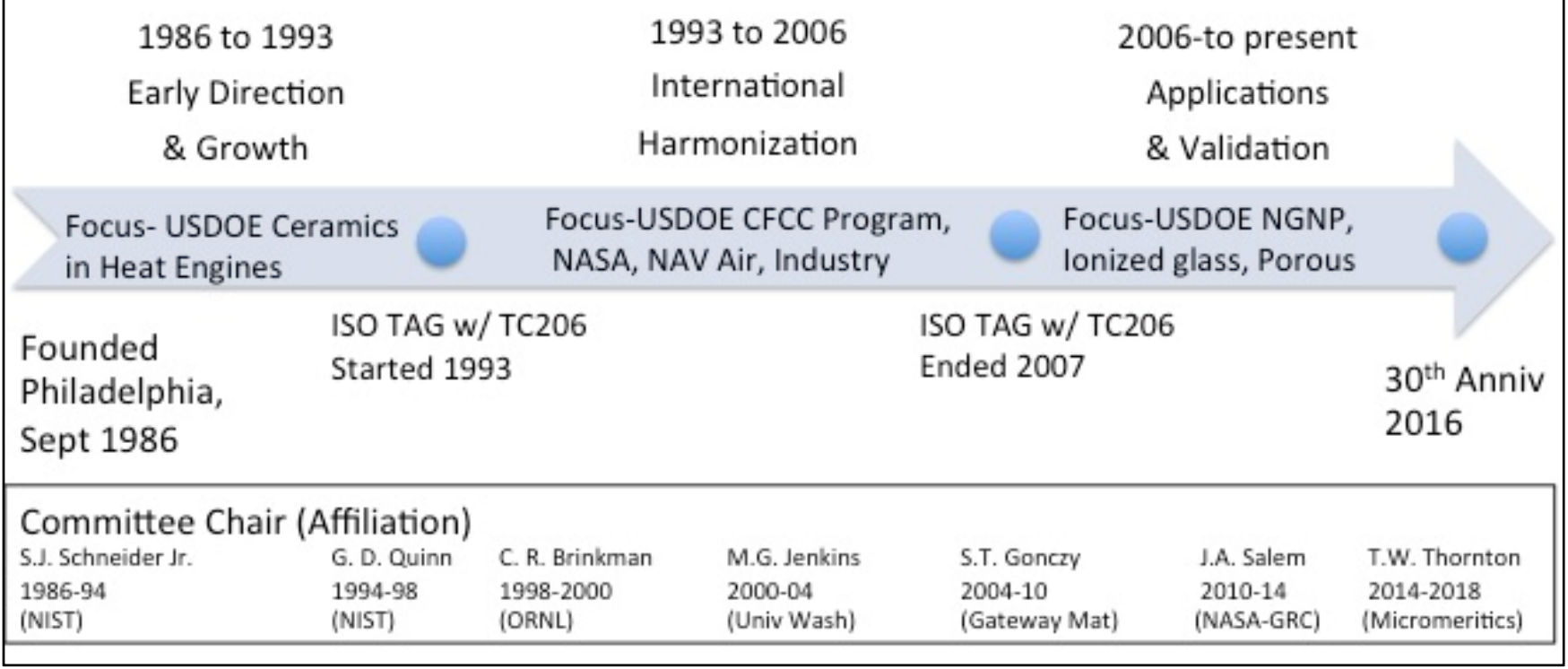

Figure 1 - Timeline for three decades of ASTM Committee C28

\section{Committee C28: Early Years - Direction and Growth (1986-93)}

In August 1986 at a meeting held at ASTM headquarters in Philadelphia and attended by over 150 interested parties, ASTM Committee C28 Advanced Ceramics was formed. Members included a wide range of interested parties from industry, government facilities, and universities. These members were classified as producers (those who made ceramic materials or products), users (those who used ceramic materials or products in components or devices) and general interest (those did not have a commercial interest in ceramics or ceramic components/devices). As it turned out the peak membership of Committee was in 1986 when interest was the greatest but the hard work of writing standards and bringing them to publication through a full-consensus balloting and approval process had not yet begun. Figure 1 illustrates the membership of Committee C28 from the early years through the transition years to the application years.

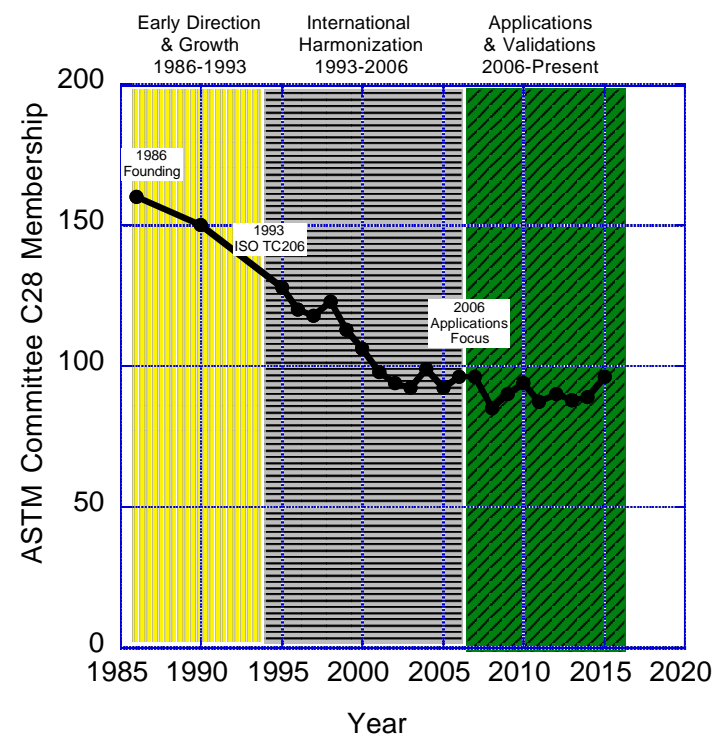

Figure 2-Membership of ASTM Committee C28 from 1986 to Present 
It is interesting that the early leadership of Committee C28 reflected organizations that had strong interest in the commercial and technological success of advanced ceramics. For example the inaugural chair (Samuel Schneider, Jr) and vice chair (George Quinn) were affiliated with the Ceramics Division of National Institute for Standards and Technology (NIST) within the US Department of Commerce. In addition, Charles Brinkman and Robert McClung of the Metals and Ceramics Division at Oak Ridge National Laboratory (US Department of Energy) along with David Cranmer of NIST were the chairs of subcommittees C28.01 Properties and Performance, C28.02 Design and Evaluation and C28.07 Ceramic Composites, respectively.

The direction of Committee C28 was dictated primarily by the perceived needs of programs for insertion of advanced ceramics in heat engines. These programs were primarily driven and funded by US federal government agencies and involved issues relevant to processing and characterization of ceramics as well as design with ceramics, including reliability.

The organization of Committee C28 in the early years consisted of three administrative committees and four technical subcommittees as follows:

Administrative

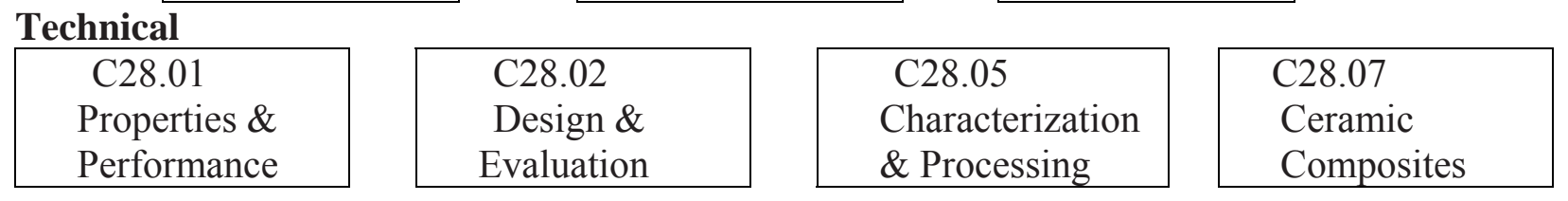

Although Committee C28 began in 1986, the first standard developed and approved under its jurisdiction was Test Method C1161 on flexure testing at room temperature, first published in 1990. It is interesting that Test Method C1161 evolved from MIL STD 1942 (MR), "Flexural Strength of Advanced Ceramics at Ambient Temperature," which had been adopted in November 1983. Many years of effort had already gone into MIL STD 1942 including error analysis, procedures for test specimen preparation, round robin testing, etc. However, the development and subsequent publication of Test Method C1161 still required much effort in refining information contained in MIL STD 1942 and reconfiguring it into an ASTM standard.

It is important to note that the general process of developing a standard involves the following steps:

1) Establish of task group of experts (both within and outside ASTM);

2) Create a work item and prepare a draft standard;

3) Ballot the draft standard at the subcommittee level;

4) If approved with no negative ballots, ballot the draft standard at the committee and society, levels.

5) If approved at the committee levels, the standard is published as a separate or within volume in the ASTM Annual Book of Standards.

These steps may take up to two years or more to complete. If any negative ballots are received at any level these must be resolved before the balloting can proceed to the next level, thus ensuring the full-consensus approval process. It is important to note that all ASTM standards must undergo a mandatory review process every five years during which they must be either reapproved or revised, so are to maintain the relevancy and currency of published standards. Standards under the jurisdiction of Committee C28 are published in Volume 15.01 in the ASTM Annual Book of Standards. Standards under the jurisdiction of Committee C28 that were approved and published during the early years of the committee include the following as shown in Table 1. 
Table 1 - ASTM Committee C28 standards developed and published in its Early Years (1986-93)

\begin{tabular}{|l|l|c|c|}
\hline $\begin{array}{l}\text { Number (current } \\
\text { version year) }\end{array}$ & Title & $\begin{array}{l}\text { Year Approved \& } \\
\text { First Published }\end{array}$ & $\begin{array}{l}\text { Current Responsible } \\
\text { Subcommittee }\end{array}$ \\
\hline C1145 (2013) & Terminology on Advanced Ceramics & 1990 & C28.91 \\
\hline C1161 (2013) & $\begin{array}{l}\text { Test Method for Flexural Strength of Advanced Ceramics at } \\
\text { Ambient Temperature }\end{array}$ & 1990 & C28.01 \\
\hline C1175 (2010) & $\begin{array}{l}\text { Guide to Test Methods for Nondestructive Testing of } \\
\text { Advanced Ceramics }\end{array}$ & 1991 & C28.05 \\
\hline C1198 (2013) & $\begin{array}{l}\text { Test Method for Dynamic Young's Modulus, Shear } \\
\text { Modulus, and Poisson's Ratio for Advanced Ceramics by } \\
\text { Sonic Resonance }\end{array}$ & 1991 & \\
\hline C1211 (2013) & $\begin{array}{l}\text { Test Method for Flexural Strength of Advanced Ceramics at } \\
\text { Elevated Temperature }\end{array}$ & 1992 & C28.01 \\
\hline C1212 (2015) & $\begin{array}{l}\text { Practice for Fabricating Ceramic Reference Specimens } \\
\text { Containing Seeded Voids }\end{array}$ & $\begin{array}{l}\text { C28.02 } \\
\text { Parameters for Advanced Ceramics }\end{array}$ & C28.02 \\
\hline C1239 (2013) & $\begin{array}{l}\text { Strength Data and Estimating Weibull Distribution } \\
\end{array}$
\end{tabular}

\section{Committee C28: Transition Years - International Harmonization (1993-2006)}

In 1993, two developments occurred that would dramatically alter the next decade of Committee C28: 1) The rise of ISO TC206 and 2) The growth of the CFCC Program and continued support of ceramics in heat engines projects in US DOE.

The first development reflected a natural evolution in standards writing organizations (SWOs) and that was the internationalization of standards that had evolved from organizational to national to regional to, finally, international standards. This evolution should, in theory, lead to the harmonization of the various organizational/national/regional standards into one international standard that reflects best practices, insights, methodologies and interpretations contained in these other standards. ISO TC206 Fine (technical, advanced) Ceramics was formally established in late 1992 with its first plenary meeting in 1994 at which Samuel Schneider of NIST (the first chair of Committee C28) presided as chair of ISO TC206, a position he held until 2003. As points of reference, several major national and regional SWOs from which ISO TC206 harmonized its standards included CEN TC184 on Technical Ceramics (est. 1989), ASTM C28 on Advanced Ceramics (est. 1986), JIS R on Fine Ceramics (est. 1979), BSI RPI/13 on Technical Ceramics (est. 1984), DIN NMP291 on Technical Ceramics (est. 1987) to name a few. Early membership of ISO TC206 included 10 participating (P) and 22 observer (O) countries.

Committee C28 created a new subcommittee, C28.94 ISO TC206 Technical Advisory Group (TAG) to work with ISO TC206. Since the official US representation to ISO is through ANSI, the C28.04 TAG acted only in an advisory role to ANSI for official ISO TC206 matters. In its evolution from its formation in 1993 to its dissolution in 2006, Subcommittee C28.94 developed bylaws in which technical experts were identified for various ISO TC206 efforts, subcommittees balloted on various stages of ISO TC206 activities and delegates for ISO TC206 plenary meetings were selected. One of the challenges of maintaining an ANSI/ISO TAG is financial because ANSI demands an annual fee to maintain each ISO TC affiliation (this fee is paid by ASTM but charged to the relevant committee which relies on voluntary, often industry-sourced, revenues) and delegates to international meeting incur travel costs that must somehow be met. Another challenge to maintaining an ANSI/ISO TAG is the time commitment because in addition to advancing and maintaining its own ASTM standards with a primarily national membership, Committee members must advance and maintain ISO standards with an international membership. Although participation of Committee C28 members in ISO TC206 was initially vigorous and productive (see Table 2), the financial and time burdens along with politics within ASTM International to promote its own standards as international, led to the decision within Committee C28 to officially discontinue its direct participation in ISO TC206 and to dissolve Subcommittee C28.94 in 2006. Note that ISO TC206 continues to this day with $18 \mathrm{P}$ and $13 \mathrm{O}$ member countries. 
Table 2 - ISO Standards developed with Committee C28 expertise and/or using relevant Committee C28 standards

\begin{tabular}{|c|c|c|c|c|}
\hline $\begin{array}{l}\text { ISO TC206 } \\
\text { Number }\end{array}$ & $\begin{array}{l}\text { Title ISO TC206 Fine ceramics } \\
\text { (advanced ceramics, advanced } \\
\text { technical ceramics)- }\end{array}$ & $\begin{array}{l}\text { Year } \\
\text { Approved }\end{array}$ & $\begin{array}{l}\text { Relevant ASTM C28 } \\
\text { Standard }\end{array}$ & $\begin{array}{l}\text { ASTM C28 Project } \\
\text { Convenor/US } \\
\text { Expert }\end{array}$ \\
\hline ISO 14703 & $\begin{array}{l}\text { Sample preparation for the } \\
\text { determination of particle size } \\
\text { distribution of ceramic powders }\end{array}$ & 2000 & $\begin{array}{l}\text { C1282 Test Method for } \\
\text { Determining the Particle Size } \\
\text { Distribution of Advanced } \\
\text { Ceramics by Centrifugal Photo } \\
\text { sedimentation }\end{array}$ & $\begin{array}{l}\text { S. G. Malghan (NIST) - } \\
\text { US Expert }\end{array}$ \\
\hline ISO 14704 & $\begin{array}{l}\text { Test method for flexural strength of } \\
\text { monolithic ceramics at room } \\
\text { temperature }\end{array}$ & 2000 & $\begin{array}{l}\text { C1161 Test Method for Flexural } \\
\text { Strength of Advanced Ceramics at } \\
\text { Ambient Temperature }\end{array}$ & $\begin{array}{l}\text { G.D. Quinn (NIST) - } \\
\text { Convenor/US Expert }\end{array}$ \\
\hline ISO 14705 & $\begin{array}{l}\text { Test method for hardness of } \\
\text { monolithic ceramics at room } \\
\text { temperature }\end{array}$ & 2000 & $\begin{array}{l}\text { - C1326 Test Method for Knoop } \\
\text { Indentation Hardness of } \\
\text { Advanced Ceramics } \\
\text { - C1327 Test Method for Vickers } \\
\text { Indentation Hardness of } \\
\text { Advanced Ceramics }\end{array}$ & $\begin{array}{l}\text { G.D. Quinn (NIST) - } \\
\text { Convenor/US Expert }\end{array}$ \\
\hline ISO 15490 & $\begin{array}{l}\text { Test method for tensile strength of } \\
\text { monolithic ceramics at room } \\
\text { temperature }\end{array}$ & 2000 & $\begin{array}{l}\text { C1273 Test Method for Tensile } \\
\text { Strength of Monolithic Advanced } \\
\text { Ceramics at Ambient } \\
\text { Temperatures }\end{array}$ & $\begin{array}{l}\text { M. G. Jenkins (UW, } \\
\text { Seattle) -US Expert }\end{array}$ \\
\hline ISO 15165 & Classification system & 2001 & $\begin{array}{l}\text { C1291 Classification for } \\
\text { Advanced Ceramics }\end{array}$ & $\begin{array}{l}\text { S.J. Schneider, Jr. } \\
\text { (NIST) - Convenor/US } \\
\text { Expert }\end{array}$ \\
\hline ISO 15733 & $\begin{array}{l}\text { Test method for tensile stress-strain } \\
\text { behaviour of continuous fibre- } \\
\text { reinforced composites at room } \\
\text { temperature }\end{array}$ & 2001 & $\begin{array}{l}\text { C1275 Test Method for } \\
\text { Monotonic Tensile Behavior of } \\
\text { Continuous Fiber-Reinforced } \\
\text { Advanced Ceramics with Solid } \\
\text { Rectangular Cross-Section at } \\
\text { Ambient Temperatures }\end{array}$ & $\begin{array}{l}\text { M. G. Jenkins (UW, } \\
\text { Seattle)-Convenor/US } \\
\text { Expert }\end{array}$ \\
\hline ISO 17561 & $\begin{array}{l}\text { Test method for elastic moduli of } \\
\text { monolithic ceramics at room } \\
\text { temperature by sonic resonance }\end{array}$ & 2002 & $\begin{array}{l}\text { C1198 Test Method for Dynamic } \\
\text { Young's Modulus, Shear } \\
\text { Modulus, and Poisson's Ratio for } \\
\text { Advanced Ceramics by Sonic } \\
\text { Resonance }\end{array}$ & $\begin{array}{l}\text { S.T. Gonczy (Gateway } \\
\text { Materials Tech)-US } \\
\text { Expert }\end{array}$ \\
\hline ISO 18757 & $\begin{array}{l}\text { Determination of specific surface } \\
\text { area of ceramic powders by gas } \\
\text { adsorption using the BET method }\end{array}$ & 2003 & $\begin{array}{l}\text { C1274 Test Method for Advanced } \\
\text { Ceramic Specific Surface Area by } \\
\text { Physical Adsorption }\end{array}$ & $\begin{array}{l}\text { H. Giesche } \\
\text { (Alfred University)-US } \\
\text { Expert }\end{array}$ \\
\hline ISO 15732 & $\begin{array}{l}\text { Test method for fracture toughness } \\
\text { of monolithic ceramics at room } \\
\text { temp. by single edge precracked } \\
\text { beam (SEPB) method }\end{array}$ & 2003 & $\begin{array}{l}\text { C1421 Test Methods for the } \\
\text { Determination of Fracture } \\
\text { Toughness of Advanced Ceramics }\end{array}$ & $\begin{array}{l}\text { I. Bar-on (WPI) -US } \\
\text { Expert }\end{array}$ \\
\hline ISO 17565 & $\begin{array}{l}\text { Test method for flexural strength of } \\
\text { monolithic ceramics at elevated } \\
\text { temperature }\end{array}$ & 2003 & $\begin{array}{l}\text { C1211 Test Method for Flexural } \\
\text { Strength of Advanced Ceramics at } \\
\text { Elevated Temperature }\end{array}$ & $\begin{array}{l}\text { G.D. Quinn (NIST) - } \\
\text { Convenor/US Expert }\end{array}$ \\
\hline ISO 18756 & $\begin{array}{l}\text { Determination of fracture } \\
\text { toughness of monolithic ceramics at } \\
\text { room temp by surface crack in } \\
\text { flexure (SCF) method }\end{array}$ & 2003 & $\begin{array}{l}\text { C1421 Test Methods for the } \\
\text { Determination of Fracture } \\
\text { Toughness of Advanced Ceramics }\end{array}$ & $\begin{array}{l}\text { G.D. Quinn (NIST) - } \\
\text { Convenor/US Expert }\end{array}$ \\
\hline ISO 20501 & $\begin{array}{l}\text { Weibull statistics for } \\
\text { strength data }\end{array}$ & 2003 & $\begin{array}{l}\text { C1239 Strength Data and } \\
\text { Estimating Weibull Distribution } \\
\text { Parameters for Advanced } \\
\text { Ceramics }\end{array}$ & $\begin{array}{l}\text { S.F. Duffy } \\
\text { (CSU, USA) - } \\
\text { Convenor/US Expert }\end{array}$ \\
\hline ISO 18754 & $\begin{array}{l}\text { Determination of density } \\
\text { and apparent porosity }\end{array}$ & 2003 & & R. Weber-US Expert \\
\hline ISO 20507 & Vocabulary & 2003 & $\begin{array}{l}\text { C1145 Terminology on Advanced } \\
\text { Ceramics }\end{array}$ & $\begin{array}{l}\text { J.A. Salem (NASA- } \\
\text { GRC) -US Expert }\end{array}$ \\
\hline ISO 18753 & $\begin{array}{l}\text { Determination of absolute } \\
\text { density of ceramic powders by } \\
\text { pycnometer }\end{array}$ & 2004 & & R. Weber-US Expert \\
\hline
\end{tabular}


Table 2 (cont'd)- ISO Standards developed with Committee C28 expertise and/or using relevant Committee $\mathrm{C} 28$ standards

\begin{tabular}{|c|c|c|c|c|}
\hline $\begin{array}{l}\text { ISO TC206 } \\
\text { Number }\end{array}$ & $\begin{array}{l}\text { Title ISO TC206 Fine ceramics } \\
\text { (advanced ceramics, advanced } \\
\text { technical ceramics)- }\end{array}$ & $\begin{array}{l}\text { Year } \\
\text { Approved }\end{array}$ & $\begin{array}{l}\text { Relevant ASTM C28 } \\
\text { Standard }\end{array}$ & $\begin{array}{l}\text { ASTM C28 Project } \\
\text { Convenor/US Expert }\end{array}$ \\
\hline ISO 24369 & $\begin{array}{l}\text { Determination of content of coarse } \\
\text { particles in ceramic powders by wet } \\
\text { sieving method }\end{array}$ & 2005 & & $\begin{array}{l}\text { H. Giesche } \\
\text { (Alfred University)-US } \\
\text { Expert }\end{array}$ \\
\hline ISO/CD 24370 & $\begin{array}{l}\text { Test method for fracture toughness } \\
\text { of monolithic ceramics at room } \\
\text { temp. by chevron notched beam } \\
\text { (CNB) method }\end{array}$ & 2005 & $\begin{array}{l}\text { C1421 Test Methods for the } \\
\text { Determination of Fracture } \\
\text { Toughness of Advanced } \\
\text { Ceramics }\end{array}$ & $\begin{array}{l}\text { J.A. Salem (NASA- } \\
\text { GRC) - Convenor/US } \\
\text { Expert }\end{array}$ \\
\hline ISO 20505 & $\begin{array}{l}\text { Test method for interlaminar shear } \\
\text { behaviour of continuous fibre- } \\
\text { reinforced composites at ambient } \\
\text { temperature }\end{array}$ & 2005 & $\begin{array}{l}\text { C1292 Test Method for Shear } \\
\text { Strength of Continuous } \\
\text { Fiber-Reinforced Advanced } \\
\text { Ceramics at Ambient } \\
\text { Temperatures }\end{array}$ & $\begin{array}{l}\text { E. Lara-Curzio (ORNL) } \\
\text {-Convenor/US Expert }\end{array}$ \\
\hline ISO 20505 & $\begin{array}{l}\text { Test method for in-plane shear } \\
\text { behaviour of continuous fibre- } \\
\text { reinforced composites at ambient } \\
\text { temperature }\end{array}$ & 2005 & $\begin{array}{l}\text { C1292 Test Method for Shear } \\
\text { Strength of Continuous } \\
\text { Fiber-Reinforced Advanced } \\
\text { Ceramics at Ambient } \\
\text { Temperatures }\end{array}$ & $\begin{array}{l}\text { E. Lara-Curzio (ORNL) } \\
\text {-Convenor/US Expert }\end{array}$ \\
\hline ISO 18755 & $\begin{array}{l}\text { Determination of thermal } \\
\text { diffusivity of monolithic ceramics by } \\
\text { laser flash method }\end{array}$ & 2005 & & $\begin{array}{l}\text { D.P.H. Hasselman (PSU) } \\
\text {-US Expert }\end{array}$ \\
\hline ISO 20502 & $\begin{array}{l}\text { Determination of adhesion } \\
\text { of ceramic coatings by scratch } \\
\text { testing }\end{array}$ & 2005 & & $\begin{array}{l}\text { P. J. Blau (ORNL)-US } \\
\text { Expert }\end{array}$ \\
\hline ISO 22214 & $\begin{array}{l}\text { Test method for cyclic bending } \\
\text { fatigue of monolithic ceramics at } \\
\text { room temperature }\end{array}$ & 2006 & & $\begin{array}{l}\text { M. G. Jenkins (U Detroit } \\
\text { Mercy)-US Expert }\end{array}$ \\
\hline ISO 22215 & $\begin{array}{l}\text { Test method for tensile creep of } \\
\text { monolithic ceramics }\end{array}$ & 2006 & $\begin{array}{l}\text { C1291 Test Method for } \\
\text { Elevated Temperature Tensile } \\
\text { Creep Strain, Creep Strain } \\
\text { Rate, and Creep } \\
\text { Time-to-Failure for Advanced } \\
\text { Monolithic Ceramics }\end{array}$ & $\begin{array}{l}\text { W. Luecke (NIST)-US } \\
\text { Expert }\end{array}$ \\
\hline ISO 20504 & $\begin{array}{l}\text { Test method for compressive } \\
\text { behaviour of continuous } \\
\text { fibre-reinforced composites at } \\
\text { ambient temp. }\end{array}$ & 2006 & $\begin{array}{l}\text { C1358 Test Method for } \\
\text { Monotonic Compressive } \\
\text { Strength Testing of Continuous } \\
\text { Fiber-Reinforced Advanced } \\
\text { Ceramics with Solid } \\
\text { Rectangular Cross-Section } \\
\text { Specimens at Ambient } \\
\text { Temperatures }\end{array}$ & $\begin{array}{l}\text { M. G. Jenkins (U Detroit } \\
\text { Mercy) -Convenor/US } \\
\text { Expert }\end{array}$ \\
\hline ISO/CD 24235 & $\begin{array}{l}\text { Determination of particle size } \\
\text { distribution of ceramic powders by } \\
\text { laser diffraction method }\end{array}$ & 2007 & $\begin{array}{l}\text { C1070-14 Test Method for } \\
\text { Determining Particle Size } \\
\text { Distribution of Alumina or } \\
\text { Quartz by Laser Light } \\
\text { Scattering }\end{array}$ & $\begin{array}{l}\text { H. Giesche } \\
\text { (Alfred University)-US } \\
\text { Expert }\end{array}$ \\
\hline
\end{tabular}

The second development was a well-funded broad-based program funded by US DOE and driven by industrial and aerospace applications of continuous fibre ceramic composites (CFCCs). It was recognized that CFCCs were the enabling technology for many types of advanced technologies that included chemical and petroleum refineries, next generation nuclear power, aerospace planes, gas turbines and scramjets. Because CFCCs were fabricated quite differently than monolithic ceramics and behaved quite differently (i.e., nonlinear stress strain curve indicative of a cumulative damage, fracture resistant response), unique test methods were required. Eventually, eleven standards for CFCCs were developed and published during the period. In addition, two symposia (see Table 3) related to CFCCs were organized during this period that resulted in two STPs (STP 1309 and 1392). Membership and participation in Subcommittee C28.07 Ceramic Composites grew during this time as well. 
Table 3 - ASTM Special Technical Publications (STP) sponsored by Committee C28

\begin{tabular}{|l|l|l|l|}
\hline STP Number & Title & Year & Symposium Location \\
\hline STP 1201 & $\begin{array}{l}\text { Life Prediction Methodologies and Data for Ceramic } \\
\text { Materials }\end{array}$ & 1994 & $\begin{array}{l}\text { Cocoa Beach, FL, Jan 1993 } \\
\text { w/ACerS }\end{array}$ \\
\hline STP 1309 & $\begin{array}{l}\text { Thermal and Mechanical Test Methods and Behavior of } \\
\text { Continuous-Fiber Ceramic Composites }\end{array}$ & 1996 & $\begin{array}{l}\text { Cocoa Beach, FL, Jan 1996 } \\
\text { w/ACerS }\end{array}$ \\
\hline STP 1392 & $\begin{array}{l}\text { Mechanical, Thermal and Environmental Testing and } \\
\text { Performance of Ceramic Composites and Components }\end{array}$ & 2000 & Seattle, WA, May 1999 \\
\hline STP 1409 & $\begin{array}{l}\text { Fracture Resistance Testing of Monolithic and Composite } \\
\text { Brittle Materials }\end{array}$ & 2002 & Orlando, FL, Nov 2000 \\
\hline
\end{tabular}

During this same period, efforts funded by US DOE in the area of insertion of ceramics in advanced heat engines also drove development of standards for monolithic advanced ceramics. In particular, contracts for fabrication and processing of ceramics included requirements for uniaxial, uniform testing (e.g., tension and compression). Long-term performance requirements for ceramic engine components required standards for creep, slow crack growth. Many years of development finally led to a comprehensive standard for fracture toughness testing of monolithic that included three different techniques that give remarkably consistent results for a NIST provided standard reference material (SRM 2100). These efforts also lead to two other symposia that resulted in two additional STPs for monolithic and composite ceramics (STP 1201 on life prediction/data and STP 1409 on fracture resistance).

Also, occurring during this period was the development by Committee $\mathrm{C} 28$ of an ASTM-required, long-range plan (LRP). As part of this plan, a new permanent subcommittee on long range planning (Subcommittee C28.95) was established. The goals contained in the first LRP for Committee C28 introduced 2000 were as follows:

1) Maintain and update existing ASTM standards for advanced ceramics with emphasis on those that are most widely used.

2) Maintain and update existing ISO standards for advanced ceramics for which the committee has been convenor through its TAG.

3) Develop new standards for advanced ceramics that can provide support for evolving specifications, design codes and data bases

4) Develop new standards for advanced ceramics that can provide support for applications that are non structural based on user needs

5) Coordinate and disseminate information on advanced ceramics through standards, symposia and publications.

This LRP also included details of an operating plan that addressed development and maintenance of national and international standards for advanced ceramics as well as organization, leadership, membership, outreach and funding of Committee C28. As part of outreach, a summary and compilation of Committee C28 standards was created as a faux newsletter, called "Advanced Ceramic Sentinel." This publication (see front page in Figure 2) was distributed on the web, at meetings and for a time on a CD as a hypertext linked interactive document. Similarly, a pictorial compilation of C28 standards was developed and distributed in poster form (see Figure 3).

While the number of new standards under Committee C28 grew rapidly during this period, the Committee also engaged in its first mandatory review of existing standards per ASTM requirements. That is, individual standards must be re-approved or revised every five years or they will be subject to mandatory withdrawal as active standards. This requirement assures that standards remain relevant and up to date. Figure 4 graphically represents the number of standards under jurisdiction of Committee $\mathrm{C} 28$ from its inception to the present as well as number of standards requiring review in any given year. 


\title{
Advanced Ceramic Sentinel
}

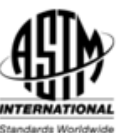

\author{
An Information Summary for \\ ASTM Committee C28 on Advanced Ceramics \\ January 2016 - Celebrating 30 years of Excellence
}

\section{Scope of Committee C28}

The promotion of knowledge, stimulation of research and development of standards (classifications, specifications, nomenclature, test methods, guides, and practices) relating to processing, properties, characterization, and performance of advanced ceramic materials.

This committee works in concert with other technical committees (e.g., D30 "Composite Materials," E07 "Non Destructive Testing," E08 "Fatigue and Fracture," E28 "Mechanical Testing," F04 "Medical and Surgical Materials and Devices", and G02 "Wear and Erosion") and other national and international organizations having mutual or related interests.

\section{What Committee C28 Does}

Committee C28 develops and maintains standards for monolithic and composite advanced ceramics. An advanced ceramic is a highly-engineered, highperformance predominately non-metallic, inorganic, ceramic material having specific functional attributes. The C28 standards cover methods for testing bulk and constituent (powders, fibres, etc.) properties, thermal and physical properties, strengths and strength distributions, and performance under varying environmental, thermal, and mechanical conditions. The scope of application of the methods ranges from quality control through design data generation.

The Committee's primary objective is the development of technically rigorous standards which are accessible to the general industrial laboratory and consequently are widely accepted and used in the design, production, and utilization of advanced ceramics.

While the committee's roots are in energy-related industries and programs, C28 supports the needs of automotive, aerospace, electronic, medical and other industries requiring advanced ceramics. Some specific applications include nano-ceramics, bio-ceramics, coatings, electronics, sensors/actuators, porous substrates and fuel cells. C28 actively pursues standards development to support these emerging applications.

Committee C28 coordinates its work with other organizations with mutual interests in advanced ceramics. The membership represents an international group of people interested in furthering advanced ceramic technology.

In addition to standards development, C28 sponsors symposia providing a forum for the timely transfer of technical information relevant to the design, analysis, processing, fabrication, and characterization of monolithic and composite advanced ceramics. Special workshops and technical presentations are often held to identify specific industrial needs and support the technical development of new standards.

The Committee meets twice a year in with an on-site meeting and a Web-teleconference. The Committee is self-regulated by committee-approved by-laws under the auspices of ASTM International

\begin{tabular}{|c|c|c|c|c|}
\hline \multicolumn{5}{|c|}{$\begin{array}{lc} & \text { COMMITTEE C28 - ADVANCED CERAMICS } \\
& \text { 2016-18 Officers and Committee Structure } \\
\text { Chair: } & \text { Tony Thornton, Micromeritics } \\
\text { Vice Chair: } & \text { Michael Jenkins, Bothell Eng \& Science Technologies } \\
\text { Recording Secretary: } & \text { Stephen Gonczy, Gateway Materials Technology } \\
\text { Membership Secretary: Jonathan Salem, NASA Glenn Research Center }\end{array}$} \\
\hline $\begin{array}{l}\text { C28.90 } \\
\text { Executive }\end{array}$ & $\begin{array}{c}\text { C28.92 } \\
\text { Education / Outreach }\end{array}$ & $\begin{array}{l}\text { C28.93 } \\
\text { Awards }\end{array}$ & $\begin{array}{c}\text { C28.95 } \\
\text { Long Range Planning } \\
\end{array}$ & \\
\hline $\begin{array}{c}\text { C28.01 } \\
\text { Mechanical } \\
\text { Properties and } \\
\text { Reliability }\end{array}$ & \begin{tabular}{|c|} 
C28.03 \\
Physical Properties \\
and NDE
\end{tabular} & $\begin{array}{c}\text { C28.04 } \\
\text { Ceramic } \\
\text { Applications }\end{array}$ & $\begin{array}{c}\text { C28.07 } \\
\text { Ceramic Matrix } \\
\text { Composites }\end{array}$ & $\begin{array}{c}\text { C28.91 } \\
\text { Nomenclature and } \\
\text { Editorial }\end{array}$ \\
\hline
\end{tabular}

Figure 2 - Front page of Advanced Ceramic Sentinel used for outreach 


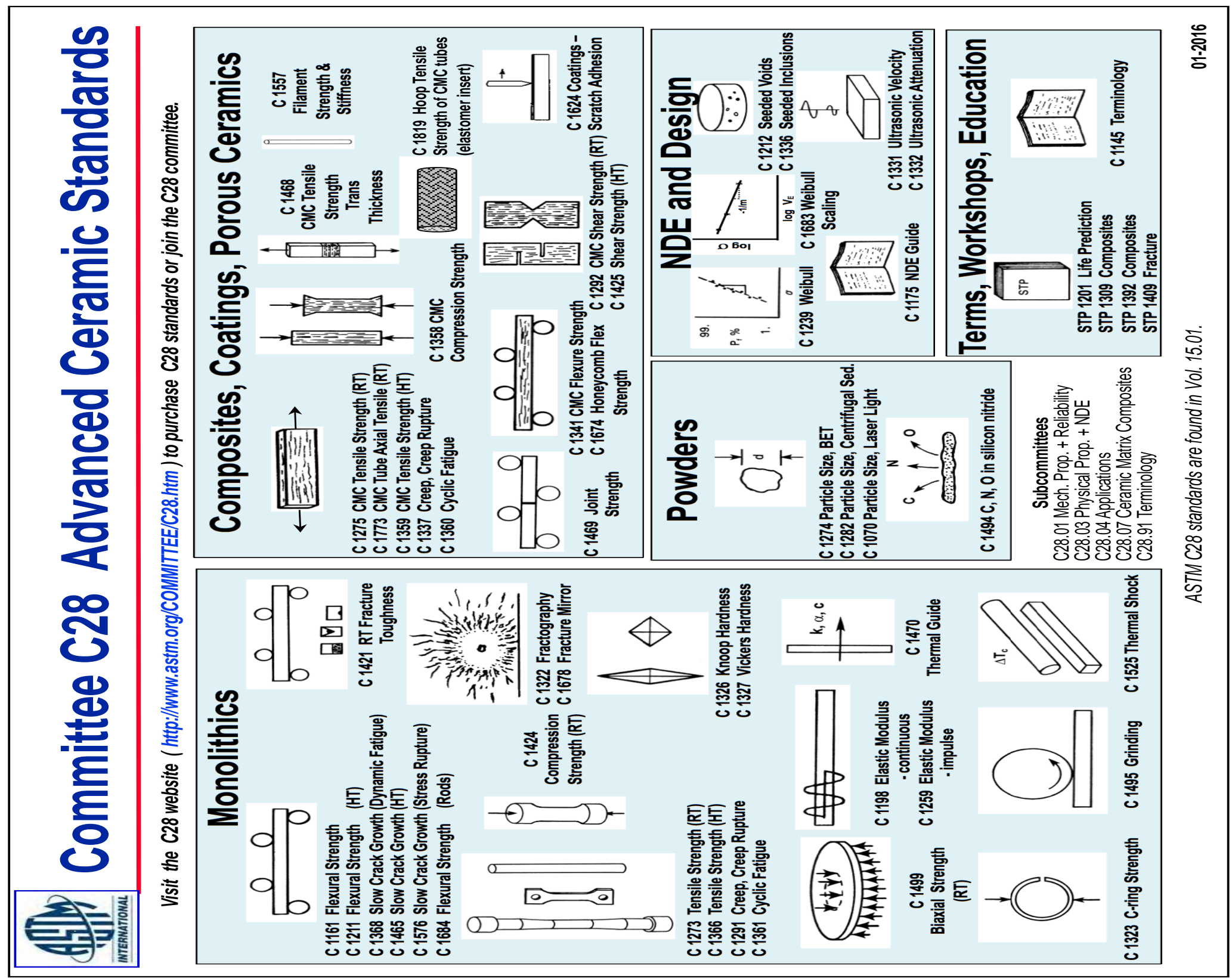

Figure 3-Pictorial illustration of Committee C28 standards 


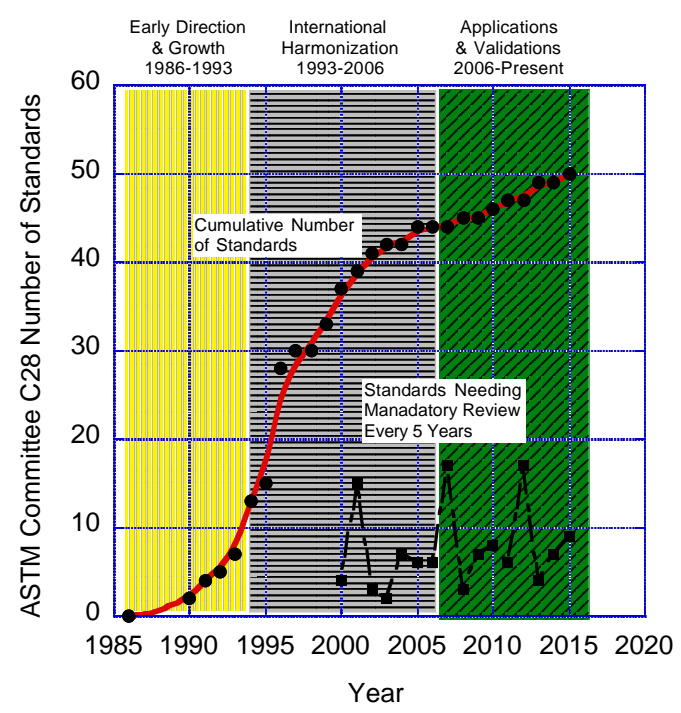

Figure 4-Cumulative number of Committee $\mathrm{C} 28$ standards and number of standard needing mandatory review in any given year

Organizational the subcommittee structure of Committee $\mathrm{C} 28$ changed during this period as well with addition of two administrative subcommittees and the reorganization and renaming of several technical subcommittees. Part of this reorganization was the result of developing a long-range plan that including a refocus on userspecific standards (i.e., applications). Some areas that were impacting applications including liaisons with MilHdbk-17 on Composites, ASTM Boiler and Pressure Vessel Code and Gas Research Institute. This reorganization is illustrated as follows.

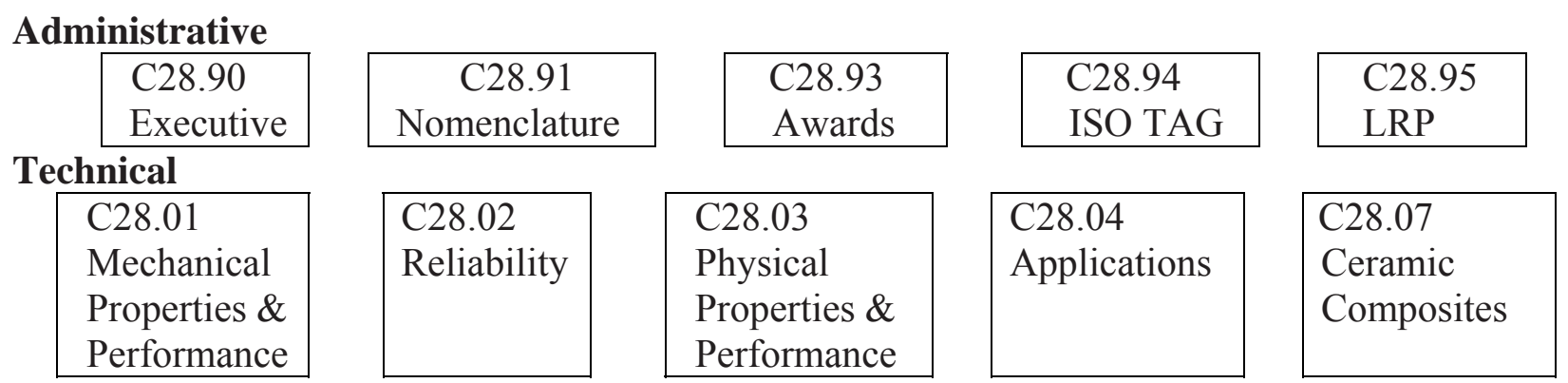

Another change that was implemented for a short time was the semi-annual meeting location and schedule. Since its inception, Committee C28 had sought to develop a close relationship with ACerS by scheduling one of its twice-a-year meetings in conjunction one of the major meetings of ACerS. Up until about 1999, Committee C28 had been meeting in January at the "Cocoa Beach" conference of ACerS in January and then wherever ASTM was meeting in May/June in order to interact with fellow ASTM committees such as E08 on Fatigue and Fracture or D30 on Composites. Starting in with 2000, Committee C28 changed its meeting schedule such that its April/May meeting was in conjunction with the ACerS annual meeting and its November meeting was during an ASTM committee week. Part of the motivation for this change was to interact with a broader ceramics community. In addition, Committee C28 organized sessions on standards at the ACerS annual meeting in order to educated and reach out the broader ceramics community.

A summary of standards developed and published in the transition years is contained in Table 4 . 
Table 4 - ASTM Committee C28 standards developed and published in its Transition Years (1993-2006)

\begin{tabular}{|c|c|c|c|}
\hline $\begin{array}{l}\text { Number } \\
\text { (current version } \\
\text { year) }\end{array}$ & Title & $\begin{array}{l}\text { Year Approved \& } \\
\text { First Published }\end{array}$ & $\begin{array}{l}\text { Current } \\
\text { Responsible } \\
\text { Subcommittee } \\
\end{array}$ \\
\hline C1259 (2015) & $\begin{array}{l}\text { Test Method for Dynamic Young's Modulus, } \\
\text { Shear Modulus, and Poisson's Ratio for } \\
\text { Advanced Ceramics by Impulse Excitation of } \\
\text { Vibration }\end{array}$ & 1994 & $\mathrm{C} 28.01$ \\
\hline C1273 (2015) & $\begin{array}{l}\text { Test Method for Tensile Strength of Monolithic } \\
\text { Advanced Ceramics at Ambient Temperatures }\end{array}$ & 1994 & \\
\hline C1274 (2012) & $\begin{array}{l}\text { Test Method for Advanced Ceramic Specific } \\
\text { Surface Area by Physical Adsorption }\end{array}$ & 1994 & $\mathrm{C} 28.03$ \\
\hline C1275 (2015) & $\begin{array}{l}\text { Test Method for Monotonic Tensile Behavior of } \\
\text { Continuous Fiber-Reinforced Advanced } \\
\text { Ceramics with Solid Rectangular Cross-Section } \\
\text { at Ambient Temperatures }\end{array}$ & 1994 & $\mathrm{C} 28.07$ \\
\hline $\begin{array}{l}\text { C1282 (2008) } \\
\text { withdrawn 2014 }\end{array}$ & $\begin{array}{l}\text { Test Method for Determining the Particle Size } \\
\text { Distribution of Advanced Ceramics by } \\
\text { Centrifugal Photo-sedimentation }\end{array}$ & 1995 & $\mathrm{C} 28.02$ \\
\hline $\begin{array}{l}\text { C1286 (1994) } \\
\text { withdrawn 2001 }\end{array}$ & Classification for Advanced Ceramics & 1994 & $\mathrm{C} 28.91$ \\
\hline C1291 (2010) & $\begin{array}{l}\text { Test Method for Elevated Temperature Tensile } \\
\text { Creep Strain, Creep Strain Rate, and Creep } \\
\text { Time-to-Failure for Advanced Monolithic } \\
\text { Ceramics }\end{array}$ & 1995 & $\mathrm{C} 28.01$ \\
\hline C1292 (2010) & $\begin{array}{l}\text { Test Method for Shear Strength of Continuous } \\
\text { Fiber-Reinforced Advanced Ceramics at } \\
\text { Ambient Temperatures }\end{array}$ & 1995 & $\mathrm{C} 28.07$ \\
\hline C1322 (2015) & $\begin{array}{l}\text { Practice for Fractography and Characterization } \\
\text { of Fracture Origins in Advanced Ceramics }\end{array}$ & 1996 & $\mathrm{C} 28.01$ \\
\hline C1323 (2010) & $\begin{array}{l}\text { Test Method for Ultimate Strength of Advanced } \\
\text { Ceramics with Diametrally Compressed C-Ring } \\
\text { Specimens at Ambient Temperature }\end{array}$ & 1996 & $\mathrm{C} 28.04$ \\
\hline C1326 (2013) & $\begin{array}{l}\text { Test Method for Knoop Indentation Hardness of } \\
\text { Advanced Ceramics }\end{array}$ & 1996 & $\mathrm{C} 28.01$ \\
\hline C1327 (2015) & $\begin{array}{l}\text { Test Method for Vickers Indentation Hardness of } \\
\text { Advanced Ceramics }\end{array}$ & 1996 & $\mathrm{C} 28.01$ \\
\hline C1331 (2012) & $\begin{array}{l}\text { Practice for Measuring Ultrasonic Velocity in } \\
\text { Advanced Ceramics with the Broadband } \\
\text { Pulse-Echo Cross-Correlation Method }\end{array}$ & 1996 & $\mathrm{C} 28.03$ \\
\hline C1332 (2013) & $\begin{array}{l}\text { Test Method for Measurement of Ultrasonic } \\
\text { Attenuation Coefficients of Advanced Ceramics } \\
\text { by the Pulse-Echo Contact Technique }\end{array}$ & 1996 & $\mathrm{C} 28.03$ \\
\hline C1336 (2014) & $\begin{array}{l}\text { Practice for Fabricating } \\
\text { Reference Specimens } \\
\text { Inclusions }\end{array}$ & 1996 & $\mathrm{C} 28.03$ \\
\hline C1337 (2015) & $\begin{array}{l}\text { Test Method for Creep and Creep Rupture of } \\
\text { Continuous Fiber-Reinforced Ceramic } \\
\text { Composites under Tensile Loading at Elevated } \\
\text { Temperature }\end{array}$ & 1996 & $\mathrm{C} 28.07$ \\
\hline C1341 (2013) & $\begin{array}{l}\text { Test Method for Flexural Properties of } \\
\text { Continuous Fiber-Reinforced Advanced Ceramic } \\
\text { Composites }\end{array}$ & 1996 & $\mathrm{C} 28.07$ \\
\hline C1358 (2013) & $\begin{array}{l}\text { Test Method for Monotonic Compressive } \\
\text { Strength Testing of Continuous } \\
\text { Fiber- Reinforced Advanced Ceramics with } \\
\text { Solid Rectangular Cross-Section Specimens at } \\
\text { Ambient Temperatures }\end{array}$ & 1996 & $\mathrm{C} 28.07$ \\
\hline
\end{tabular}


Table 4 (cont'd)-ASTM Committee C28 standards developed and published in its Transition Years (1993-2006)

\begin{tabular}{|c|c|c|c|}
\hline $\begin{array}{l}\text { Number } \\
\text { (current version } \\
\text { year) }\end{array}$ & Title & $\begin{array}{l}\text { Year Approved \& } \\
\text { First Published }\end{array}$ & $\begin{array}{c}\text { Current } \\
\text { Responsible } \\
\text { Subcommittee } \\
\end{array}$ \\
\hline C1359 (2013) & $\begin{array}{l}\text { Test Method for Monotonic } \text { Tensile Strength } \\
\text { Testing of Continuous Fiber-Reinforced } \\
\text { Advanced Ceramics with Solid Rectangular } \\
\text { Cross-Section Specimens at Elevated } \\
\text { Temperatures }\end{array}$ & 1996 & $\mathrm{C} 28.07$ \\
\hline C1360 (2013) & $\begin{array}{l}\text { Practice for Constant-Amplitude, Axial, } \\
\text { Tension-Tension Cyclic Fatigue of Continuous } \\
\text { Fiber-Reinforced Advanced Ceramics at } \\
\text { Ambient Temperatures }\end{array}$ & 1996 & $\mathrm{C} 28.07$ \\
\hline C1361 (2015) & $\begin{array}{l}\text { Practice for Constant-Amplitude, Axial, } \\
\text { Tension-Tension Cyclic Fatigue of Advanced } \\
\text { Ceramics at Ambient Temperatures }\end{array}$ & 1996 & $\mathrm{C} 28.01$ \\
\hline C1366 (2013) & $\begin{array}{l}\text { Test Method for Tensile Strength of Monolithic } \\
\text { Advanced Ceramics at Elevated Temperatures }\end{array}$ & 1997 & $\mathrm{C} 28.01$ \\
\hline C1368 (2010) & $\begin{array}{l}\text { Test Method for Determination of Slow Crack } \\
\text { Growth Parameters of Advanced Ceramics by } \\
\text { Constant Stress-Rate Flexural Testing at } \\
\text { Ambient Temperature }\end{array}$ & 1997 & $\mathrm{C} 28.01$ \\
\hline C1421 (2015) & $\begin{array}{l}\text { Test Methods for the Determination of Fracture } \\
\text { Toughness of Advanced Ceramics }\end{array}$ & 1999 & $\mathrm{C} 28.01$ \\
\hline C1424 (2015) & $\begin{array}{l}\text { Test Method for Compressive Strength of } \\
\text { Monolithic Advanced Ceramics at Ambient } \\
\text { Temperatures }\end{array}$ & 1999 & $\mathrm{C} 28.01$ \\
\hline C1425 (2013) & $\begin{array}{l}\text { Test Method for Interlaminar Shear Strength of } \\
1-D \text { and 2-D CFCCs at Elevated Temperatures }\end{array}$ & 1999 & $\mathrm{C} 28.07$ \\
\hline C1465 (2013) & $\begin{array}{l}\text { Test Method for Determination of Slow Crack } \\
\text { Growth Parameters of Advanced Ceramics by } \\
\text { Constant Stress-Rate Flexural Testing at } \\
\text { Elevated Temperature }\end{array}$ & 2000 & $\mathrm{C} 28.01$ \\
\hline C1468 (2013) & $\begin{array}{l}\text { Test Method for Transthickness Tensile } \\
\text { Strength of Continuous Fiber- Reinforced } \\
\text { Advanced Ceramics at Ambient Temperatures }\end{array}$ & 2000 & $\mathrm{C} 28.07$ \\
\hline C1469 (2010) & $\begin{array}{l}\text { Test Method for Shear Strength of Joints of } \\
\text { Advanced Ceramics at Ambient Temperature }\end{array}$ & 2000 & $\mathrm{C} 28.07$ \\
\hline C1470 (2013) & $\begin{array}{l}\text { Guide for Testing the Thermal Properties of } \\
\text { Advanced Ceramics }\end{array}$ & 2000 & $\mathrm{C} 28.03$ \\
\hline C1494 (2013) & $\begin{array}{l}\text { Test Method for Determination of Mass Fraction } \\
\text { of Carbon, Nitrogen, and Oxygen in Silicon } \\
\text { Nitride Powder }\end{array}$ & 2001 & $\mathrm{C} 28.03$ \\
\hline C1495 (2012) & $\begin{array}{l}\text { Test Method for Effect of Surface Grinding on } \\
\text { Flexure Strength of Advanced Ceramics }\end{array}$ & 2001 & $\mathrm{C} 28.01$ \\
\hline C1499 (2013) & $\begin{array}{l}\text { Test Method for Monotonic Equibiaxial Flexural } \\
\text { Strength Testing of Advanced Ceramics at } \\
\text { Ambient Temperature }\end{array}$ & 2002 & $\mathrm{C} 28.01$ \\
\hline C1525 (2012) & $\begin{array}{l}\text { Test Method for Determination of Thermal } \\
\text { Shock Resistance for Advanced Ceramics by } \\
\text { Water Quenching }\end{array}$ & 2002 & $\mathrm{C} 28.01$ \\
\hline C1557 (2014) & $\begin{array}{l}\text { Test Method for Tensile Strength and Young's } \\
\text { Modulus Fibers }\end{array}$ & 2003 & $\mathrm{C} 28.07$ \\
\hline C1576 (2013) & $\begin{array}{l}\text { Test Method for Determination of Slow Crack } \\
\text { Growth Parameters of Advanced Ceramics by } \\
\text { Constant Stress Flexural Testing (Stress } \\
\text { Rupture) at Ambient Temperature }\end{array}$ & 2005 & $\mathrm{C} 28.01$ \\
\hline C1624 (2015) & $\begin{array}{l}\text { Test Method for Adhesion Strength and } \\
\text { Mechanical Failure Modes of Ceramic Coatings } \\
\text { by Quantitative Single Point Scratch Testing }\end{array}$ & 2005 & $\mathrm{C} 28.04$ \\
\hline
\end{tabular}




\section{Committee C28: Present Years - Applications and Validations (2006-Present)}

Reflection on the long-range plan and the increasing time-commitment to duality of development/upkeep of ASTM standards and the development/upkeep of ISO TC206 standards, Committee C28 made a decision to reassess its role standards development. That reassessment occurred about the time more emphasis was being placed on applications of such as ionized glass for touch screens, electrolytes for solid oxide fuel cells (SOFCs), windows in aerospace applications, porous ceramics for filters, traps and substrates, and joining materials for ceramic joints. In addition, a new initiative from US-DOE called Next Generation Nuclear Power (NGNP) was calling for new standards to assess the mechanical, physical, and thermal behaivour of CFCC materials in unique shapes such as tubes.

Committee C28 was once again reorganized to reflect changes in direction. A major change was the decision to withdraw official participation ISO TC206 which would significantly reduce time and financial commitments. This change also eliminated the need for Subcommittee C28.94. In addition, it was decided to focus more effort on education and outreach in order the "get the word out" on C28 standards and their applications. This decision lead to the creation of Subcommittee C28.92 Education and Outreach. The new organizational structure is illustrated as follows.

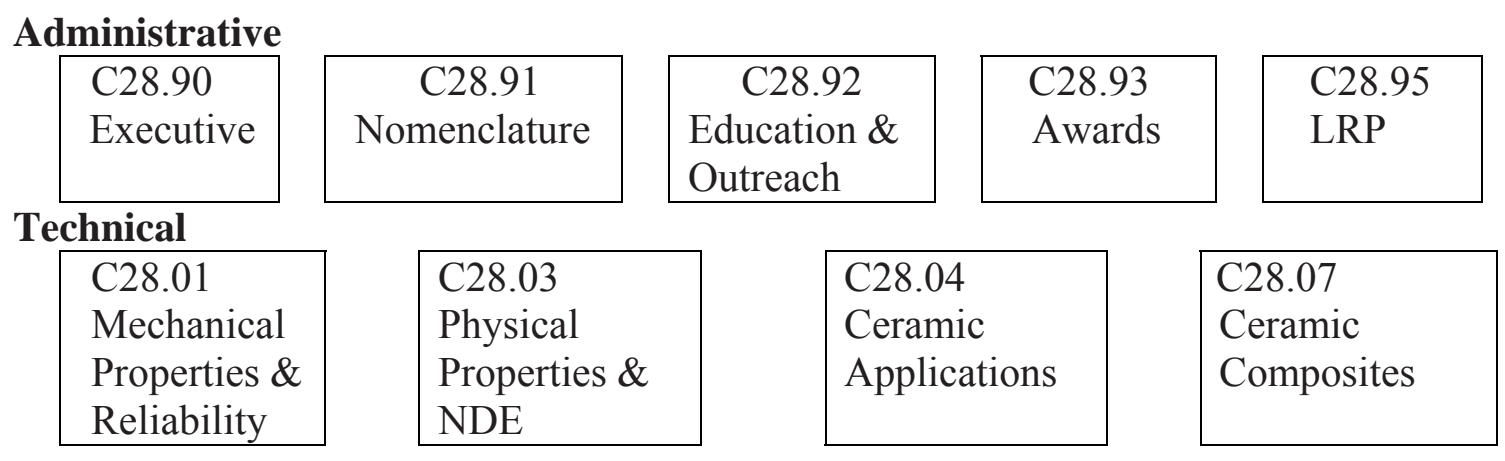

Some brief details of subcommittee within Committee C28 are as follows.

In 2006, Committee C28 once again changed its meeting schedule back to the original one of meeting in January at the "Cocoa Beach" conference of ACerS and then wherever ASTM was meeting in May/June in order to interact with fellow ASTM committees such as E08 on Fatigue and Fracture or D30 on Composites. The decision was made based on the realization that January time, the Cocoa Beach location, and the smaller ACerS conference provided better interaction those who mattered in the ceramics community than the constantly shifting and much larger annual ACerS annual meeting. However, Committee C28 soon decided that for economy of both time and finances, a teleconference meeting might be better investment for its midyear meeting. As a result, the current, and relatively successful twice-a-year meeting schedule for Committee C28 is as follows: Late January in conjunction with ACerS International Conference on Advanced Ceramics and Composites (ICACC) in Daytona Beach, Florida and in mid July as a WebX teleconference.

Reflecting its emphasis on education and outreach, Committee C28 has presented a poster standard for ceramics at the Poster Session of the ICACC for the last half decade. Recently, the Committee has created a Linked In presence. Other initiatives include regular articles in ASTM's Standardization News and ACerS's Ceramic Technology burst e-mail and Ceramic Bulletin. 
It should be noted that one of the hallmarks of ASTM standards that contributes to their technical rigor and quality is the Precision and Bias (P\&B) statement. The P\&B statement is required by ASTM in all test methods and provides the user with insight on the repeatability (precision) of the procedures and their accuracy (i.e., bias) to some known reference material. Typically round robin test programmes per ASTM E691-99 "Standard Practice for Conducting an Interlaboratory Study to Determine the Precision of a Test Method" are used to produce inter- and intra-laboratory repeatability values. Over the years members of Committee $\mathrm{C} 28$ have been instrumental in organizing, participating, interpreting and applying round robins for validating not just C28 standards but ISO and other SWO standards as well. Table 5 provides a brief summary of many of these round robins.

Table 5-Partial list of many of the round robins that have contributed to standards for ceramics

\begin{tabular}{|c|c|}
\hline Sponsor: ASTM-International and Focus & Standard P\&B Benefit \\
\hline - $\quad$ Young's Modulus and Poisson's Ratio & ASTM C1259 \\
\hline Flexural Strength of Ceramic Matrix Composites & ASTM C1341 \\
\hline Trans-Laminar Tensile Strength of Ceramic Composites & ASTM C1468 \\
\hline Tensile Creep of Silicon Nitride & ASTM C1291 \\
\hline \multicolumn{2}{|l|}{ Sponsor: International Energy Agreement (IEA) } \\
\hline - $\quad$ Flexural Strength Testing of Ceramics & ASTM C1161 \\
\hline Effect of Machining Conditions on the Strength of Silicon Nitride & ASTM C1495 \\
\hline Tensile Strength Testing of Ceramics & ASTM C1273 \\
\hline \multicolumn{2}{|c|}{ Sponsor: Versailles Project on Advanced Materials and Standards(VAMAS) } \\
\hline - Fracture Toughness by the Surface Crack Method & ASTM C1421 \\
\hline Fracture Toughness of Silicon Nitride at High Temperature & JIS 1617 \\
\hline Fractography of Advanced Ceramics & ASTM C1322 \\
\hline Fracture Toughness of Advanced Ceramics at Room Temperature & ASTM C1421 \\
\hline Fracture Toughness of Ceramic Matrix Composite & \\
\hline Fracture Toughness of Ceramics using the SEVNB Method & \\
\hline - Inert Strength of Ceramics & \\
\hline \multicolumn{2}{|l|}{ Sponsor: US DOE CFCC Programme } \\
\hline - $\quad$ Tensile, Flexure and Shear Behavior of a Ceramic Matrix Composite & $\begin{array}{l}\text { ASTM C1275, C1292, } \\
\text { C1341, C1468 }\end{array}$ \\
\hline
\end{tabular}


The current subcommittee structure and their functions are summarized as follows.

C28.90 Executive This subcommittee manages administrative matters of main Committee C28 through its membership comprised of the committee and subcommittee officers of C28.

C28.91 Nomenclature and Editorial This subcommittee compiles nomenclature and terminology used in the various standards of Committee C28.

C28.92 Education and Outreach This subcommittee_develops and supports efforts for education and outreach for the $\mathrm{C} 28$ committee.

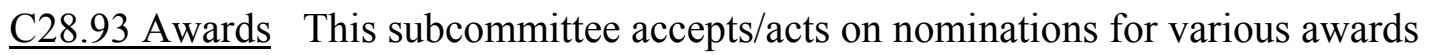

C28.95 Long Range Planning This subcommittee proposes, facilitates and promotes long range planning activities consistent with the mission.

C28.01 Mechanical Properties \& Reliability This subcommittee develops standards for mechanical properties and reliability (short term and long term) of monolithic advanced ceramics in a number of areas including flexural strength, tensile strength, compressive strength, cyclic fatigue, creep and creep rupture, hardness, and fracture toughness.

C28.03 Physical Properties \& NDE This subcommittee develops standards for physical, chemical, micro-structural, and non-destructive characterization of powder and bulk advanced ceramics.

C28.04 Applications This subcommittee develops standards (including guides, specifications, practices, test methods) for various engineering applications of advanced ceramics, such as nanoceramics, coatings, electrodes, porous ceramics, fuel cells, armor, sensors/actuators, and thermal systems.

C28.07 Ceramic Matrix Composites This subcommittee_develops standards for determination of the thermo-mechanical properties and performance of ceramic matrix composites including tension, compression, shear, flexure, cyclic fatigue, creep/creep rupture, ceramic fibers, interfacial properties, thermo-mechanical fatigue, environmental effects, and structural/component testing.

A summary of Committee C28 standards published since 2006 is shown in Table 6. 
Table 6 - ASTM Committee C28 standards developed and published in its Present Years (2006-Present)

\begin{tabular}{|c|c|c|c|}
\hline $\begin{array}{l}\text { Number (current } \\
\text { version year) }\end{array}$ & Title & $\begin{array}{l}\text { Year Approved \& } \\
\text { First Published }\end{array}$ & $\begin{array}{l}\text { Responsible } \\
\text { Subcommittee } \\
\end{array}$ \\
\hline C1683 (2015) & $\begin{array}{l}\text { Standard Practice for Size Scaling of Tensile } \\
\text { Strengths Using Weibull Statistics for Advanced } \\
\text { Ceramics }\end{array}$ & 2008 & $\mathrm{C} 28.01$ \\
\hline C1678 (2010) & $\begin{array}{l}\text { Standard Practice for Fractographic Analysis of } \\
\text { Fracture Mirror Sizes in Ceramics and Glasses }\end{array}$ & 2010 & $\mathrm{C} 28.01$ \\
\hline C1674 (2011) & $\begin{array}{l}\text { Standard Test Method for Flexural Strength of } \\
\text { Advanced Ceramics with Engineered Porosity } \\
\text { (Honeycomb Cellular Channels) at Ambient } \\
\text { Temperatures }\end{array}$ & 2011 & $\mathrm{C} 28.05$ \\
\hline C1684 (2013) & $\begin{array}{l}\text { Standard Test Method for Flexural Strength of } \\
\text { Advanced Ceramics at Ambient Temperature - } \\
\text { Cylindrical Rods }\end{array}$ & 2013 & $\mathrm{C} 28.01$ \\
\hline C1773 (2013) & $\begin{array}{l}\text { Standard Test Method for Monotonic Axial } \\
\text { Tensile Behavior of Continuous Fiber-Reinforced } \\
\text { Advanced Ceramic Tubular Test Specimens at } \\
\text { Ambient Temperature }\end{array}$ & 2013 & C28.07 \\
\hline C1819 (2015) & $\begin{array}{l}\text { Standard Test Method for Hoop Tensile Strength } \\
\text { of Continuous Fiber-Reinforced Advanced } \\
\text { Ceramic Composite Tubular Test Specimens at } \\
\text { Ambient Temperature Using Elastomeric Inserts }\end{array}$ & 2015 & $\mathrm{C} 28.07$ \\
\hline
\end{tabular}

\section{Tangible Benefits of Standards}

Although many examples of tangible benefits of ASTM C28 standards could be cited only a few are given here in the interests of brevity.

F2393 Standard Specification for High-Purity Dense Magnesia Partially Stabilized Zirconia (MgPSZ) for Surgical Implant Applications

ASTM Committee F04 on Surgical and Medical Devices and the U.S. Food and Drug Administration used generic standards from Committee C28 for their standard specification, F2393. Some specifics are as follows:

- $\quad$ "The average room temperature flexural strength shall be $600 \mathrm{MPa}(87000 \mathrm{psi}$ ) or greater by 4 point bend testing in accordance with Test Method C1161, test configuration B. A minimum of 10 samples are to be tested."

- $\quad$ "If Weibull modulus is determined, test results shall be evaluated in accordance with Practice C1239. The minimum number of test specimens shall be 30 and the minimum acceptable uncensored, unbiased Weibull modulus shall be 10."

- "The minimum room temperature elastic modulus shall be $180 \mathrm{GPa}$ (26 $200 \mathrm{ksi}$ ) in accordance with Test Method C1198. Arectangular specimen with dimensions of 60 by 10 by $3 \mathrm{~mm}$ is recommended. An acceptable alternative test method for elastic modulus is Test Method C1259."

- The minimum Vickers hardness value shall be $1000 \mathrm{HV}$ in accordance with Test Method C1327. The load shall be $9.8 \mathrm{~N}(1 \mathrm{~kg})$ and the dwell time shall be $15 \mathrm{~s}$. 


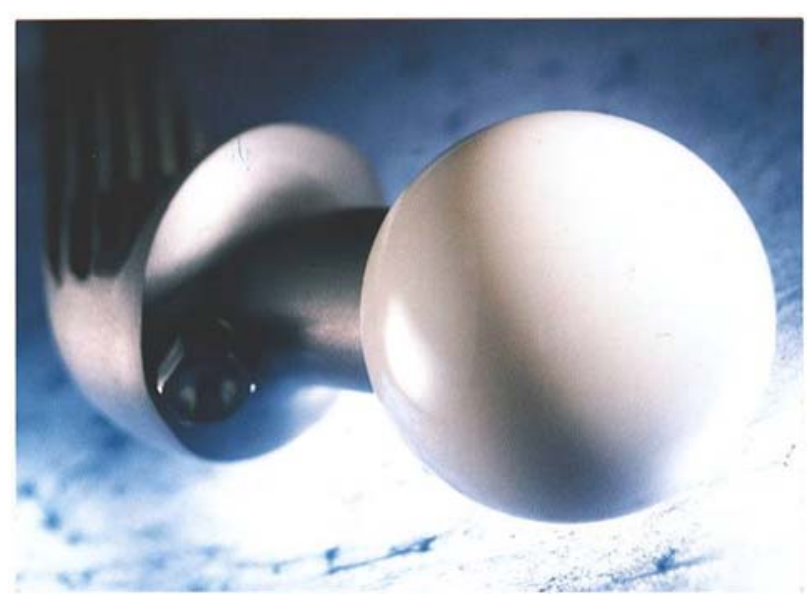

Figure 5-Example of Mg-PSZ surgical implant

\section{F2094/F2094M Standard Specification for Silicon Nitride Bearing Balls}

ASTM Committee F34 on Rolling Element Bearings used generic standards from Committee C28 for their standard specification, F2094. Some specifics are as follows:

- $\quad$ "Either 3-point or 4-point test methods may be used for flexural strength, which should be measured in accordance with Test Method C1161 (size B)..."

- "Fracture resistance shall be measured by either ..... (see Annex A1) or by a standard fracture toughness test method." (C1421)

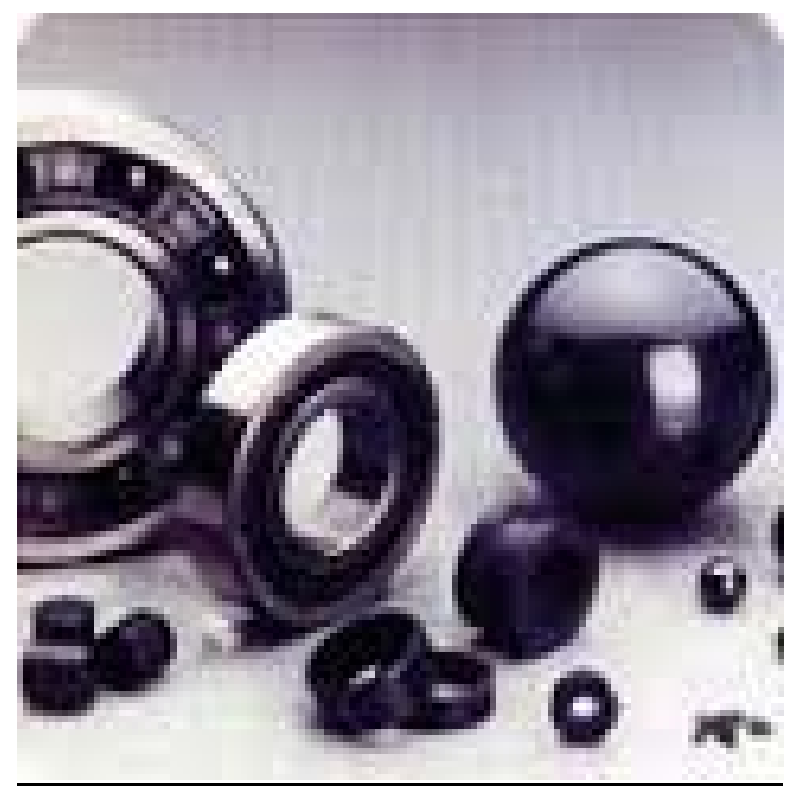

Figure 6-Examples of silicon nitride rolling elements 


\section{$\underline{\text { Transparent Armor Ceramics as Spacecraft Windows }}$}

Standards from Committee C28 allowed comparisons among authors and helped to interpret data. In particular:

- $\quad$ Standardized fracture toughness tests using Test Method C1421 ensured correct comparisons of different authors' results

- Standard-sized circular disks could be used to determine Poisson's ratio and Young's modulus via Test Method C1259 and biaxial strength via Test Method C1499 as well as the slow crack growth parameters, $\mathrm{n}$ and $\mathrm{A}$, via Test Method $\mathrm{C} 1368$. This allowed efficient understanding of the behavior of the material.

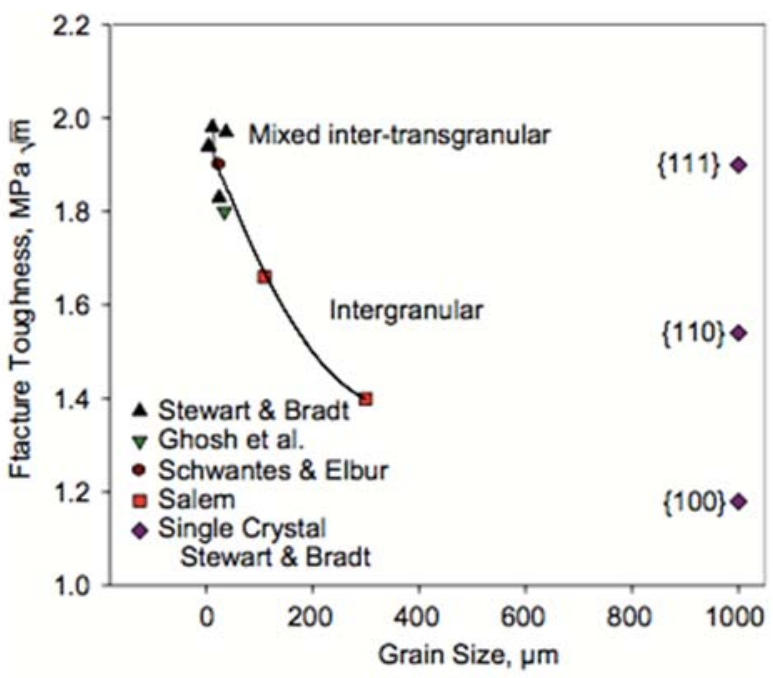

Figure 7-Fracture toughness of window material for different crystallographic planes
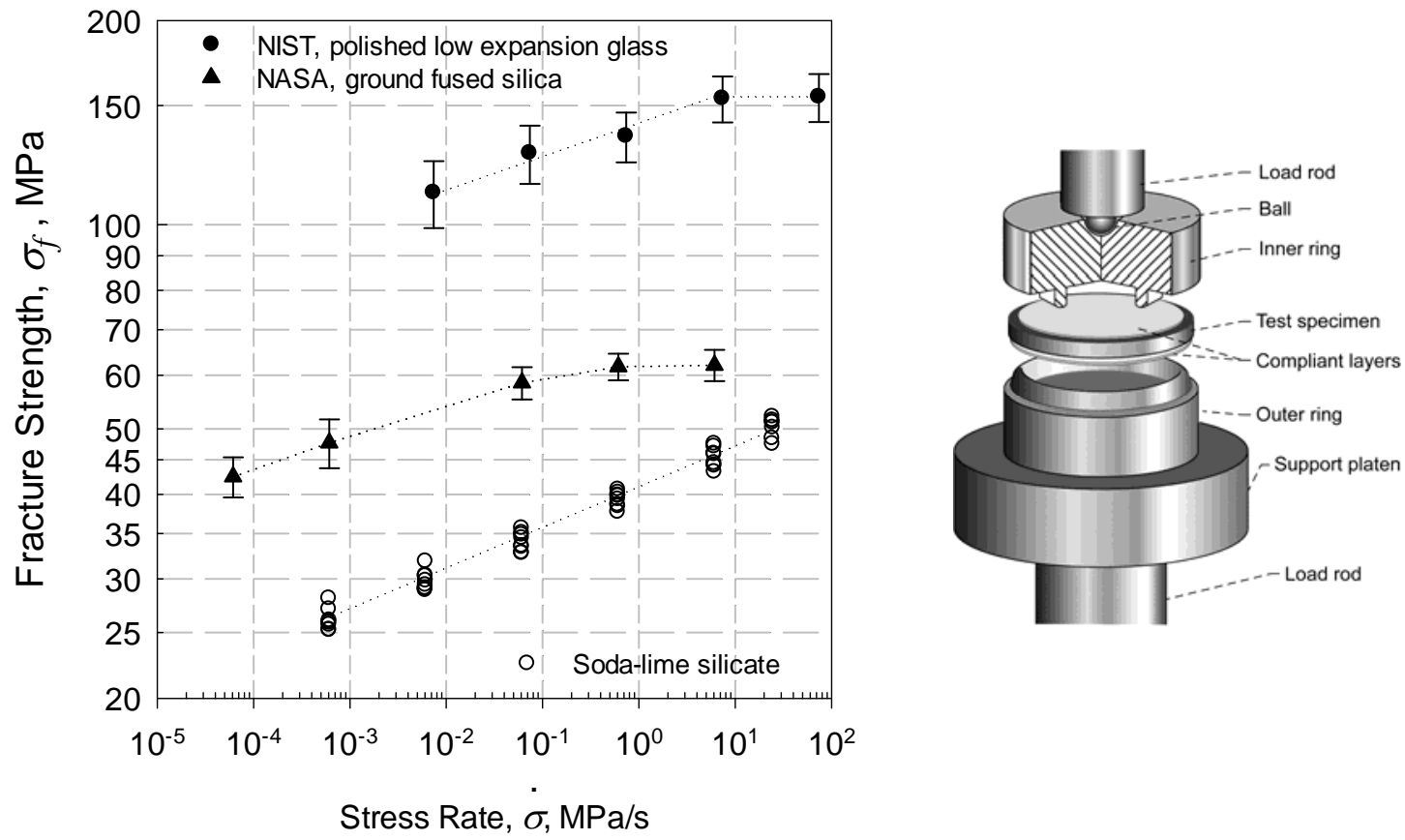

Figure 8 - Comparison of biaxial flexural strength for two window materials $\underline{\text { Standard Reference Materials }}$ 
Standard Reference Materials (SRMs) certified by NIST are available for users to verify test procedures including user techniques and test apparati. In particular:

- $\quad$ SRM 2100 was developed to improve fracture toughness testing of ceramics. It may be used with conventional testing machines and flexure (bend bar) test configurations. The SRM is a set of five hot-isostatically pressed silicon nitride test specimens. The fracture toughness is certified by billet of the SRM material. For example, Billet $\mathrm{C}$ is certified to have a mean $\mathrm{K}_{\mathrm{Ic}}=4.572 \mathrm{MPa} \cdot \mathrm{m}^{1 / 2}$ and uncertainty of $0.228 \mathrm{MPa} \cdot \mathrm{m}^{1 / 2}\left(5 \%\right.$ of mean) for a single test specimen and $0.106 \mathrm{MPa} \cdot \mathrm{m}^{1 / 2}(2.3 \%$ of mean) for all five test specimens.

- $\quad$ SRM 2830 was developed to improve Knoop hardness testing of ceramics. It may be used with conventional hardness testing machines that make indentations that are measured with an optical microscope. The SRM is prepared from a silicon nitride ceramic bearing ball in which five indentations have been made at a load of $19.6 \mathrm{~N}$ (2 kgf). Each SRM is individually certified for the size of each of the 5 indentations with average diagonal length $(\approx 142.0 \mu \mathrm{m})$, and average hardness HK2. The HK2 is nominally $13.86 \mathrm{GPa}$ or $1,414 \mathrm{HK} 2$. (Test Method C1326)

- $\quad$ SRM 2831 was developed to improve Vickers hardness testing of ceramics and hardmetals. It may be used with conventional hardness testing machines that make indentations that are measured with an optical microscope. The SRM is a hot-isostatically pressed tungsten carbide with $12 \%$ cobalt disk which has five indentations made at a load of $9.8 \mathrm{~N}$ (1 kgf). Each SRM is individually certified for the size of each of the 5 indentations, the average diagonal length $(\approx 35.0 \mu \mathrm{m})$, and the average hardness HV1. The HV 1 is nominally $15 \mathrm{GPa}$ which is in middle of the hardness range for most ceramics and cutting tool carbides (Test Method C1327)

\section{CONCLUSIONS}

Demand for advanced ceramics and ceramic matrix composites in the market place is expected to continue to grow as these materials improve in consistency and reliability, and reduced cost. Standardized test methods are expected to accelerate use of these materials as they become available and are used nationally and internationally. ASTM Committee C28 on Advanced Ceramics has produced, as of this writing, fifty high-quality, technically-rigorous consensus standards for processing, characterization, design, and evaluation of this class of materials. These activities have accelerated in recent years and many more standards are expected to be completed in the near future.

\section{ACKNOWLEDGEMENT}

This work was conducted with U.S. Department of Energy funding under the technical direction of Dr. Yutai Katoh at Oak Ridge National Laboratory, Oak Ridge, TN.

\section{REFERENCES}

1. Phillips, D., C., and Davidge, R., W., "Test Techniques for the Mechanical Properties of Ceramic Matrix Fibre Composites," Br. Ceram. Trans. J., 85, 123-130 (1986).

2. Schneider, S., J., and Bradley, D. R., "The Standardization of Advanced Ceramics," Adv. Ceram. Matls., 3[5] 442-449 (1988).

3. Jenkins, M.G. and Quinn, G.D., "ASTM Standards for Monolithic and Composite Advanced Ceramics: Industrial, Governmental and Academic Cooperation," ASME 1996 International Gas Turbine and Aeroengine Congress and Exhibition V 5, 96-GT-270, ASME International, New York, 1996.

4. Kanno, T., "International Standardization Activities for Fine Ceramics - Status of ISO/TC206 on Fine Ceramics," ASME paper 96-GT-321, presented at the International Gas Turbine and Aeroengine Congress and Exposition, Birmingham, U.K., June 10-13, 1996.

5. Steen, M., "European Standardization Efforts on Fibber-Reinforced Ceramic Matrix Composites," ASME 1996 International Gas Turbine and Aeroengine Congress and Exhibition V 5, 96-GT-269, ASME International, New York, 1996 
6. Jenkins, M. G., "Standards and Codes for Ceramic Matrix Composites," Advanced Composite Materials, V 8[1], pp. 55-76 (1999)

7. Glenny, E., "Ceramics and the Gas Turbine," in Special Ceramics 1964: Proceedings of a Symposium held by the British Ceramic Research Association, P. Popper, ed., Academic Press, London, 1965, pp. 301-315.

8. Ceramics for High Performance Applications, J.J. Burke, A.E. Gorum, and R. N. Katz, eds. Brook Hill Publishing Co., Chesnut Hill, Massachuesetts, USA, 1974

9. Lenoe, E. M., "Recent Accomplishments and Research Needs in Structural Ceramics," in Ceramics for High Performance Applications-III: Reliability, E.M. Lenoe, R. N. Katz, and J. J. Burke, eds., Plenum Press, New York, USA, 1979, pp. 3-18.

10. Brinkman, C.R., and Quinn, G. D., "Standardization of Mechanical Properties Tests for Advanced Ceramics," in "Mechanical Testing Methodology for Ceramic Design and Reliability," D. C. Cranmer and D. W. Richerson, eds, Marcel Decker, Inc, New York, USA, 1998, pp. 353-386.

11. Committee C28, "Advanced Ceramic Sentinel," ASTM International, West Conshohocken, Penn, 2016

12. Life Prediction Methodologies and Data for Ceramic Materials, ASTM STP 1201, C.R. Brinkman, and S.F. Duffy, eds., American Society for Testing and Materials, Philadelphia, Pennsylvania (1994)

13. Thermal and Mechanical Test Methods and Behaviour of Continuous Fibre Ceramic Composites, ASTM STP 1309, M.G. Jenkins, S.T. Gonczy, E. Lara-Curzio, N.E. Ashbaugh, and L.P. Zawada, eds., American Society for Testing and Materials, West Conshohocken, Pennsylvania (1997)

14. Mechanical, Thermal and Environmental Testing and Performance of Ceramic Composites and Components, ASTM STP 1392, M.G. Jenkins, E. Lara-Curzio, S. T. Gonczy, eds. American Society for Testing and Materials, West Conshohocken, Pennsylvania (2000)

15. Fracture Resistance Testing of Monolithic and Composite Brittle Materials, ASTM STP 1409, J.A. Salem, G.D. Quinn, M.G. Jenkins, eds, American Society for Testing and Materials, West Conshohocken, Pennsylvania (2002).

16. Salem, J.A., "Transparent Armor as Spacecraft Windows," J. Am.Ceram.Soc., 96 [1] pp. 281-289 (2013)

17. Salem, J.A. and Jenkins, M.G., "ASTM International Committee C28 on Advanced Ceramics: Setting standards since 1986," American Ceram. Soc. Bull., Vol. 93, No.1, Jan. 2014.

18. Freiman, Stephen W. and Quinn, George D.,"How Property Test Standards Help Bring New Materials to the Market," Standardization News, October 2001.

19. Quinn, G. D., "ASTM C-28: The First Decade," American Society Bulletin, Vol 75, No 12, pp 45-46, December 1996.

20. Brinkman, C.R, Quinn, G.D., McClung, R.W., "Development of ASTM Standards in Support of Advanced Ceramics Development-A Status Report,” ASME 93-GT-160, ASME International, New York, 1993

21. Quinn, G.D, "Does anyone know the real fracture toughness? SRM 2100: The world's first ceramic fracture toughness reference material," ASTM Special Technical Publication, n 1409, p 76-92, 2002, Fracture Resistance Testing of Monolithic and Composite Brittle Materials, J.A. Salem, G.D. Quinn, M.G. Jenkins, eds, American Society for Testing and Materials, West Conshohocken, Pennsylvania (2002).

22. Quinn, G.D., Gettings, R., Ives, L.K., "A standard reference material for Vickers hardness of ceramics and hardmetals," IMEKO TC5 Conference on Hardness Measurements Theory and Application in Laboratories and Industries, HARDMEKO 2004, p 90-97, 2004

23. Gettings, R.J.; Quinn, G.D.; Ruff, A.W.; Ives, L.K., "New hardness standard reference materials (SRM's) for advanced ceramics," Ceramic Engineering and Science Proceedings, v 15, n 5, p 817-826, Sept-Oct 1994

24. Schneider, S.J., Jr. "New materials, advanced ceramics and standards," Key Engineering Materials, v 53$55, \mathrm{p} 480-485,1991$

25. Lara-Curzio, E,; Jenkins, M.G., "Development of test standards for continuous fiber ceramic composites in the United States" Composites Part A: Applied Science and Manufacturing, v 30, n 4, p 561-567, 1999

26. Brinkman, C.R., "Development of ASTM standards in support of advanced ceramics - continuing efforts" ASME 1998 International Gas Turbine and Aeroengine Congress and Exhibition 98-GT, ASME International, New York, 1998

27. ASTM E691-99 "Standard Practice for Conducting an Interlaboratory Study to Determine the Precision of a Test Method," ASTM International, West Conshohoken, PA (2013) 